\title{
STUDI GEOTEKNIK PENGARUH MUKA AIR TANAH TERHADAP KESTABILAN LERENG TAMBANG BATUBARA
}

\author{
Jioni Santo Frans ${ }^{l)}$ dan Muhammad Hafizh Nurfalaq ${ }^{2)}$ \\ ${ }^{1}$ 'Sr. Geotechnical Engineer, Sinarmas Mining Muara Bungo, Jambi \\ ${ }^{2)}$ Teknik Geologi, Fakultas Teknologi Mineral, UPN “Veteran” Yogyakarta \\ *Email: jioni.simamora@gmail.com
}

\begin{abstract}
ABSTRAK
Dalam keadaan normal, suatu massa batuan memiliki kesetimbangan gaya yang bekerja. Kesetimbangan gaya yang bekerja tersebut bisa terganggu akibat terjadinya perubahan kondisi massa batuan, baik secara alamiah (erosi, patah, peningkatan muka air tanah) maupun aktivitas manusia (pengupasan, pengangkutan, penggalian, penimbunan). Respon dari perubahan tersebut, massa batuan dapat mengalami ketidakstabilan sebagai usaha untuk mencapai kondisi kesetimbangan baru. Hal ini akan memicu gerakan massa batuan akibat lereng yang tidak stabil dan terjadinya longsor. Lereng yang tidak stabil akan berdampak terhadap faktor keselamatan, ekonomi, dan sosial. Air tanah memiliki permasalahan tersendiri dalam pengelolaan tambang. Tekanan air pori (pore water pressure) dari air tanah dapat menimbulkan gaya angkat (uplift force) dan menurunkan kekuatan suatu massa batuan penyusun lereng, yang mana akan mempengaruhi kestabilan suatu lereng. Karakteristik daerah penelitian yang memiliki muka air tanah relatif dekat dengan permukaan, menyebabkan lereng berada dalam kondisi hampir jenuh. Penelitian ini bertujuan untuk melakukan studi pengaruh muka air tanah terhadap kestabilan lereng tambang batubara di daerah penelitian. Metode penelitian yang digunakan meliputi pengumpulan data primer melalui observasi lapangan untuk mengumpulkan data-data teknis terkait dan pengumpulan data sekunder melalui studi literatur. Analisa kestabilan lereng dilakukan untuk mendapatkan rekomendasi dengan nilai Faktor Keamanan minimum 1,30. Hasil penelitian menunjukkan muka air tanah memiliki hubungan berbanding terbalik terhadap nilai Faktor Keamanan. Rekomendasi yang dihasilkan yaitu melakukan dewatering dengan menggunakan drain hole. Target penurunan muka air tanah pada dinding tambang daerah penelitian adalah RL+40 pada area sidewall dan RL+65 pada area highwall. Altenatif lain yang diajukan oleh penulis adalah dengan melandaikan sudut lereng keseluruhan (overall slope angle) pada dinding tambang di daerah penelitian. Dinding tambang daerah penelitian direkomendasikan untuk dilakukan pelandaian dengan sudut lereng keseluruhan berkisar $24^{\circ}$.
\end{abstract}

Kata kunci: kestabilan lereng, muka air tanah, longsor, dewatering, sudut lereng keseluruhan

\begin{abstract}
Under normal circumstances, a rock mass has an equilibrium of working forces. The equilibrium of these working forces can be disrupted due to changes in rock mass conditions, both naturally (erosion, broken, increased ground water level) and human activities (stripping, loading, excavation, backfill). In response to these changes, rock mass can have instability issue as an effort to reach new equilibrium conditions. This condition will trigger rock mass movements and slope failure due to unstable slopes. Unstable slopes will affect the safety, economic and social factors. Groundwater has its own problems in mining activities. Pore water pressure from ground water can cause uplift force and decrease the strength of a rock mass forming a slope, which will affect the slope stability. Characteristics of the study area which has groundwater level relatively close to surface, causes the slope to be in nearly saturated condition. This research aims to study the effect of groundwater level on the stability of coal mine slopes in the study area. The research method used includes collecting primary data through field observations to collect related technical data
\end{abstract}


and secondary data collection through literature studies. Slope stability analysis is carried out to obtain recommendations with a minimum Safety Factor value of 1.30. The results showed the ground water level has an inverse relationship to the value of the Safety Factor. The recommendations are dewatering using drain holes. The target of groundwater level reduction in the mine wall of the study area is $R L+40$ in the sidewall area and $R L+65$ in the highwall area. Another alternative proposed by the author is by resloping the overall slope angle of the mine wall in the study area. The mining wall of the study area is recommended for alignment with an overall slope angle of around $24^{\circ}$.

Keywords: slope stability, ground water level, landslides, dewatering, overall slope angle

\section{A. PENDAHULUAN}

Kestabilan lereng dipengaruhi oleh beberapa faktor, di antaranya adalah geometri lereng, sifat fisik batuan, sifat mekanik batuan, struktur geologi, keberadaan air tanah, pelapukan, dan gaya-gaya luar. Keberadaan air, terutama air tanah (groundwater) sangat mempengaruhi kemantapan suatu lereng. Hal ini dikarenakan air tanah memiliki tekanan air pori (pore water pressure) yang dapat menimbulkan gaya angkat (uplift force) dan menurunkan kekuatan suatu massa batuan penyusun lereng. Hal ini mengakibatkan keselamatan atas unit dan manusia yang beroperasi pada area di bawah/kaki lereng berada dalam resiko bahaya yang tinggi. Di saat yang bersamaan, kegiatan di bagian atas (crest) lereng juga mengalami resiko yang meningkat.

Secara administratif daerah penelitian berlokasi di Desa Tanjung Belit, Kecamatan Jujuhan, Kabupaten Bungo, Provinsi Jambi. Secara geografis daerah penelitian terletak pada koordinat UTM (Universal Tranverse Mercator) $803200 \mathrm{mE}-805700 \mathrm{mE}$ dan $9844200 \mathrm{mS}-9846000 \mathrm{mS}$. Daerah penelitian secara umum memiliki kontur permukaan yang relatif bergelombang. Sebagian daerah penelitian telah dilakukan aktivitas penambangan, sementara area lainnya masih merupakan area hijau yang ditutupi rerumputan, semak belukar, dan pepohonan. Karakteristik lereng tambang daerah penelitian yang terdapat titik-titik rembesan (seepage) relatif dekat dengan permukaan, mengindikasikan muka air tanah yang tinggi. Kondisi aktual menunjukkan bahwa muka air tanah berada pada level $80 \%$ dari total tinggi lereng.

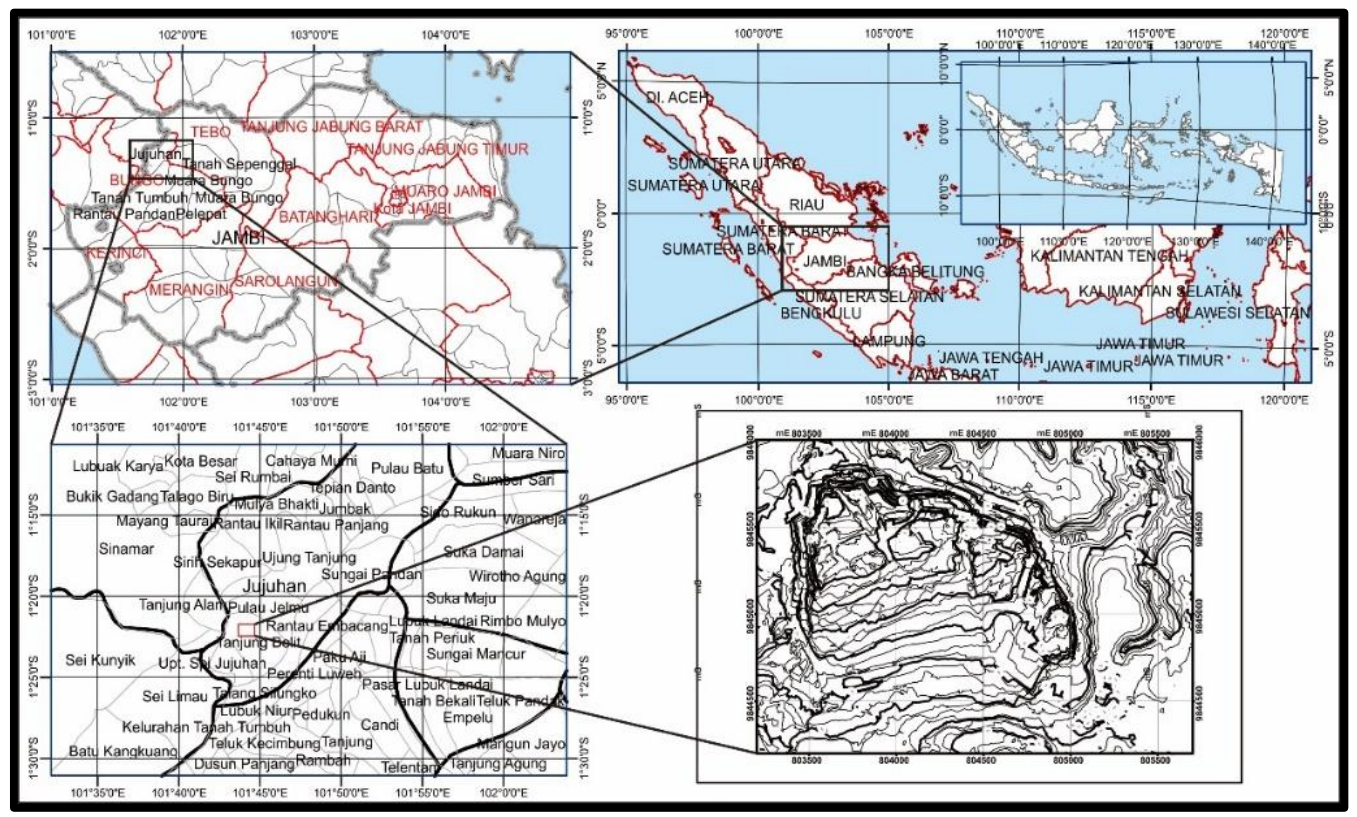

Gambar 1 Peta lokasi penelitian 
Penelitian ini memiliki tujuan untuk melakukan studi mengenai pengaruh muka air tanah terhadap kestabilan lereng tambang batubara di daerah penelitian. Sehingga dapat disusun pendekatan maupun rekomendasi slope engineering untuk mencegah terjadinya slope failure yang dipengaruhi muka air tanah.

\section{B. METODOLOGI PENELITIAN}

\section{Geologi Regional}

Secara regional, kondisi geologi daerah penelitian berada pada lembar Painan dan bagian Timur Laut lembar Siberut, Sumatra. Daerah penelitian melingkupi Formasi Sinamar yang berumur Oligiosen dengan tebal mencapai 750 meter. Formasi Sinamar (Tos) terdiri dari: batupasir, berwarna abu-abu hingga abu-abu terang, berbutir halus hingga sedang, menyudut tanggung, loose. Batulempung berwarna abu-abu hingga abu-abu kecoklatan-kemerahan, sedikit pasiran, lunak. Batulanau, berwarna abu-abu hingga abu-abu kehijauhan, kompak. Batubara berwarna hitam kusam sampai hitam mengkilap, kilap dull, agak keras, mengandung damar tebal sampai $15 \mathrm{~cm}$. Hal ini juga terkonfirmasi dengan keberadaan konglomerat, batulempung, batupasir, dan lapisan batubara di daerah penelitian. Formasi Sinamar merupakan endapan darat dengan lingkungan rawarawa (limnik).

Di atasnya diendapkan Formasi Rantau Ikil (Tmr) yang terdiri dari batulempung hijau bersifat gampingan, napal dan sisipan batugamping berlapis, mencirikan lingkungan danau. Kedua Formasi tersebut secara tidak selaras ditutupi oleh Endapan Vulkanik Kuarter yang berasal dari pegunungan barisan di sebelah Barat akibat kegiatan magmatisma. Beberapa penyelidikan terdahulu menyimpulkan, bahwa Formasi Sinamar diendapkan dalam kondisi peralihan, di mana bagian bawah formasi menunjukkan lingkungan daratan yang diendapkan pada masa Oligosen Akhir, sedangkan bagian atas formasi diendapkan dalam lingkungan laut pada masa Miosen Bawah. Endapan vulkanik tersebar tidak merata di daerah penyelidikan, terdiri dari breksi laharik, aglomerat dan konglomerat. Breksi, berwarna hitam, keras, masadasar pasir kasar tufaan, fragmen berupa batuan beku andesit, berwarna abu-abu hingga abu-abu kehitaman, bentuk membulatmenyudut tanggung, ukuran kerikil sampai boulder.

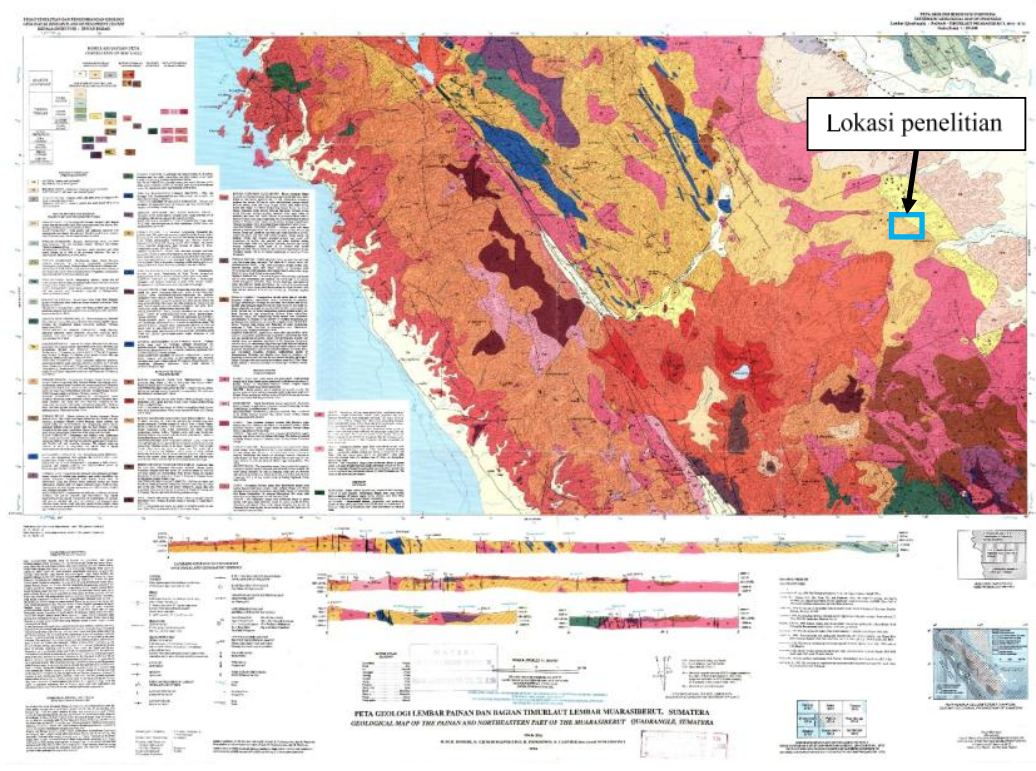

Gambar 2 Peta Geologi Lembar Painan dan bagian Timur Laut Lembar Muara Siberut, Sumatera

\section{Stratigrafi Regional}

Seperti yang sudah dijelaskan sebelumnya, pada area penelitian terdapat endapan permukaan Aluvium (Qal), Formasi Rantau Ikil (Tmr), Formasi Sinamar (Tos), endapan batuan gunung api yang tak terpisahkan (Qyu) dan endapan batuan instrusi Granit (Jgr). 
a) Endapan Aluvium (Qal)

Endapan aluvium terbentuk dari lapukan batuan (tanah), terdiri dari material lempung dan lumpur, pasir sampai kerikil. Endapan aluvium ini, umumnya terdapat pada dataran rendah dan sebagian besar berupa bantaran sungai Batanghari.

b) Formasi Rantau Ikil (Tmr)

Berupa batu pasir lempungan, batu pasir tuf, batu pasir gampingan, batu lempung pasiran, batu lempung tufaan, napal, sisipan-sisipan batubara dan lensa-lensa tipis batugamping. Formasi ini berumur Te hingga Tf (masa Oligosen akhir sampai Miosen awal). Tebal formasi ini sekurang-kurangnya 1000 meter.

c) Formasi Sinamar (Tos)

Tersusun dari konglomerat, pasir kuarsa berbutir kasar, batu pasir kuarsa mengandung mika, batupasir arkosa, batulempung, napal, batu lempung pasiran, lapisan batu bara dan batu gamping koral. Komponen konglomerat adalah kuarsit, kuarsa susu dan pecahan granit. Batu lempung, serpih dan napal semakin bertambah tebal ke arah atas. Berumur Oligosen dengan tebal $\pm 750 \mathrm{~m}$.

d) Batuan gunung api yang tak terpisahkan (Qyu)

Tersusun dari breksi gunung api, lahar, breksi tuf dan tuf, bersusunan basal sampai andesit. Batuan ini berasal dari Gunung Kerinci dan Gunung Tujuh.

e) Formasi Granit (Jgr)

Susunannya berkisar antara batu granit biotit hornblende sampai granodiorit, dengan bintikbintik mineral mafik, plagioklas dan jenis oligoklas, hornblende yang telah mengalami kloritisasi, dan secara setempat terdapat apatit. Terdapat dalam bentuk stok. Gamadiorit disimpulkan lebih muda dari Paleozoikum namun lebih tua daripada formasi Tabir (Jt) yang diperkirakan berumur Jura awal.

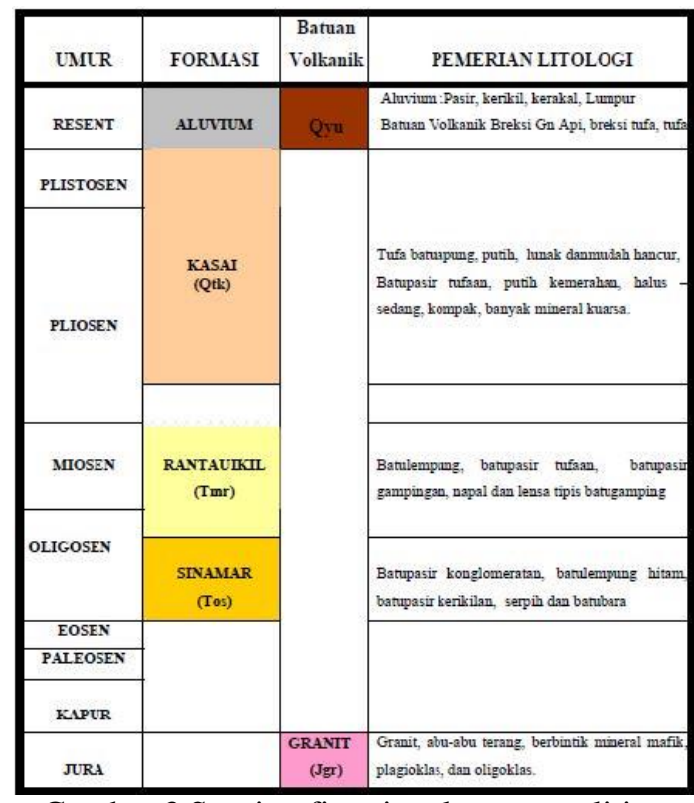

Gambar 3 Stratigrafi regional area penelitian

\section{Kondisi Hidrologi dan Hidrogeologi}

Sungai utama yang mengalir di daerah penelitian yaitu Sungai Tanjung Belit yang berada di bagian Barat area pit daerah penelitian dengan lebar sungai antara 5-10 meter. Muka air tanah pada daerah penelitian berada pada elevasi yang cukup tinggi, dekat dengan permukaan. Selain itu juga ditemukan beberapa titik rembesan air (seepage) pada dinding highwall. 


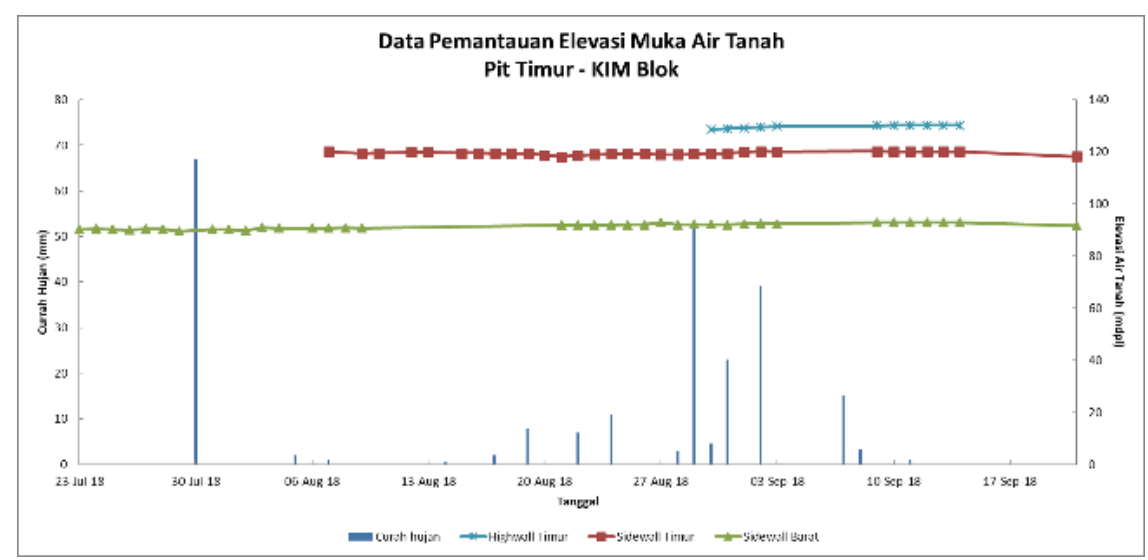

Gambar 4 Grafik pemantauan muka air tanah area penelitian

Hasil pengambilan data muka air tanah pada sumur pantau (piezometer) area sidewall sisi Timur menunjukkan muka air tanah berada pada RL+120. Pada area highwall sisi Timur, data yang didapat dari lubang piezometer menunjukkan muka air tanah berada pada RL+130. Sedangkan data pengukuran pada area sidewall dan highwall sisi Barat menunjukkan muka air tanah berada pada RL+90. Pengamatan visual di lapangan menunjukkan terdapat seepage di sepanjang lereng highwall relatif berada pada RL+95 hingga RL+115 dan untuk sisi sidewall pada RL+80 hingga RL+95. Kondisi ini mengindikasikan terjadinya proses penjenuhan pada material pembentuk lereng highwall maupun sidewall.

\section{Pengaruh Tekanan Air}

Pengaruh tekanan air pada kuat geser dapat dideskripsikan seperti sebuah bejana berisi air yang ditempatkan di atas bidang miring, seperti terlihat pada Gambar 5 di bawah ini.

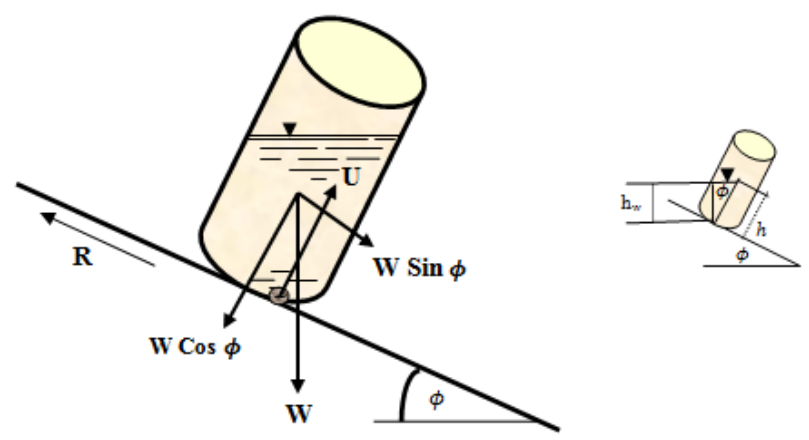

Gambar 5 Deskripsi pengaruh tekanan air terhadap kuat tekan

Jika diketahui $\mathrm{k}=0$ dan $\alpha=\phi$, dari persamaan $\mathrm{F}=\mathrm{c} \cdot \mathrm{A}+\mathrm{W} \cdot \cos \alpha \cdot \tan \phi$, maka akan diperoleh

$$
F=(W \cdot \cos \phi-U) \cdot \tan \phi
$$

di mana tekanan air sebesar $\mathrm{u}$ atau gaya angkat sebesar $\mathrm{U}=\mathrm{u}$.A, dengan $\mathrm{A}$ adalah luas dasar bejana. Jika berat satuan dari bejana dan air adalah $\gamma \mathrm{t}$ dan berat per unit volume air adalah $\gamma \mathrm{w}$, maka

$$
\begin{aligned}
& W=\gamma_{t} \cdot h \cdot A \\
& U=\gamma_{w} \cdot h_{w} \cdot A
\end{aligned}
$$


Gaya normal $\sigma_{\mathrm{n}}$ yang bekerja pada arah tegak lurus terhadap permukaan bidang gelincir dikurangi oleh gaya yang ditimbulkan oleh tekanan air u akan menjadi tegangan efektif (effective stress) yang dinyatakan dalam $\sigma_{\mathrm{n}}-\mathrm{u}$. Hubungan antara kuat geser dan tegangan normal dapat dinyatakan sebagai berikut:

$$
\tau=\left(c+\sigma_{n}-u\right) \cdot \tan \phi
$$

Selain itu, tekanan air juga memiliki pengaruh terhadap rekahan tarik. Hal ini dapat dijelaskan dengan Gambar 6, di mana sebuah balok yang berada di atas bidang miring dan dipisahkan oleh suatu rekahan tarik (tension crack) yang terisi air. V merupakan total gaya yang bekerja pada rekahan tarik yang diakibatkan oleh tekanan air yang bertambah secara linier mengikuti kedalaman. Hal ini akan mengakibatkan bertambah besarnya gaya geser (W.sin $\alpha$ ). Sedangkan U merupakan total gaya dorong ke atas yang dihasilkan tekanan air dan mengalami distribusi pada permukaan bidang geser. Hal ini akan mengurangi gaya normal yang bekerja pada permukaan bidang geser tersebut.

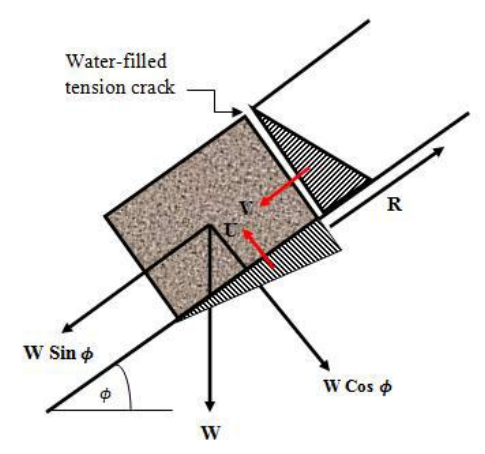

Gambar 6 Pengaruh tekanan air pada rekahan tarik

Berdasarkan kondisi kesetimbangan batas pada persamaan W.sin $\alpha=\mathrm{c} . \mathrm{A}+\mathrm{W} \cdot \cos \alpha \cdot \tan \phi$, maka akan diperoleh

$$
W \cdot \sin \alpha+V=c \cdot A+(W \cdot \cos \alpha-U) \cdot \tan \phi
$$

\section{a. Metode Kesetimbangan Batas}

Metode kesetimbangan batas memerlukan massa batuan dengan bidang permukaan yang kontinu. Bidang permukaan ini sangat penting untuk menentukan nilai Faktor Keamanan (FK) minimum. Metode ini dinyatakan dengan persamaan-persamaan kesetimbangan dari satu atau beberapa blok yang diasumsikan tidak mengalami deformasi, dan mengurangi gaya-gaya yang tidak diketahui (reaksi dari bagian stabil massa batuan atau gaya-gaya antar blok), khususnya gaya geser yang bekerja pada permukaan longsoran yang dipilih sebelumnya. Kondisi kestabilan lereng dengan menggunakan metode ini dinyatakan dalam nilai faktor keamanan. Faktor keamanan dihitung menggunakan kesetimbangan gaya atau kesetimbangan momen, maupun keduanya tergantung dari metode perhitungan yang dipakai.

Dalam keadaan tidak terganggu, massa batuan pada umumnya memiliki kesetimbangan gayagaya yang bekerja. Kesetimbangan gaya-gaya yang bekerja tersebut dapat terganggu dikarenakan adanya perubahan kondisi massa batuan, baik secara alamiah (erosi, patah, peningkatan air tanah) maupun aktivitas manusia (pengupasan, pengangkutan, penggalian, penimbunan). Dapat dilihat pada Gambar 7 di bawah ini yang memperlihatkan gaya-gaya yang bekerja pada suatu blok yang berada pada suatu bidang miring yang mempunyai sudut kemiringan sebesar $\alpha$. 


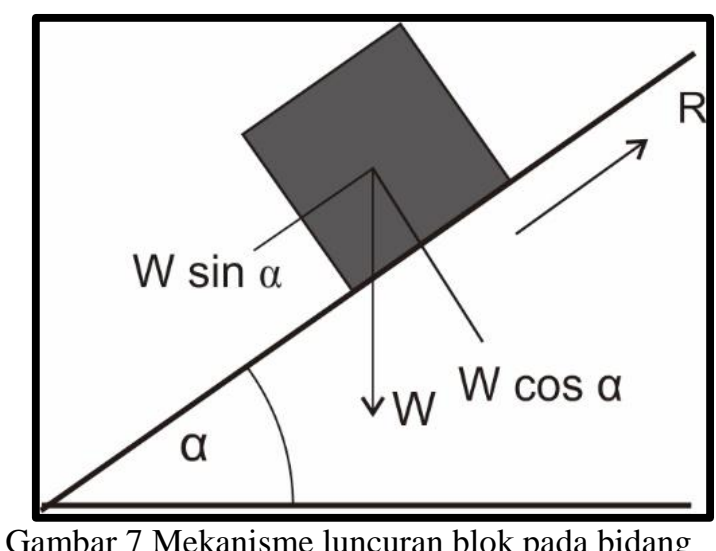

Gambar di atas menunjukkan hubungan gaya-gaya yang bekerja pada bidang miring. Gaya pendorong digambarkan sebagai gaya yang bekerja searah dengan kemiringan bidang. Sedangkan gaya normal bekerja tegak lurus terhadap permukaan bidang miring. Besarnya gaya yang dimiliki oleh benda (lereng) sebanding dengan nilai massa batuan, dan terjadinya gaya disebabkan oleh adanya gravitasi. Apabila nilai gaya penggerak yang bekerja adalah $\mathrm{W} \sin \alpha$, maka nilai FK dinyatakan dengan:

$$
F K=\frac{c+(\sigma-\mu) \tan \Phi}{W \sin \alpha}
$$

Keterangan:

$$
\begin{aligned}
& \mathrm{c}: \text { kohesi }\left(\mathrm{kN} / \mathrm{m}^{2}\right) \\
& \sigma: \text { tegangan normal }\left(\mathrm{kN} / \mathrm{m}^{2}\right) \\
& \mu: \text { tekanan air pori }\left(\mathrm{kN} / \mathrm{m}^{2}\right)
\end{aligned}
$$

$$
\begin{gathered}
\phi: \text { sudut } \\
\alpha \quad: \quad \underset{ }{2} \quad \text { sudut }
\end{gathered}
$$

Sifat- sifat material yang relevan dengan masalah kemantapan lereng adalah sudut geser dalam $(\phi)$, kohesi $(c)$, dan berat satuan $(\gamma)$ batuan. Grafik pada Gambar 8 menjelaskan secara sederhana tentang batuan yang mengandung bidang diskontinu, di mana bekerja tegangan normal dan tegangan geser, sehingga batuan retak pada bidang diskontinu dan mengalami pergeseran. Hubungan antara kuat geser $(\tau)$ dan tegangan normal $(\sigma)$ dapat dinyatakan oleh persamaan berikut:

$$
\tau=c+\sigma_{n} \tan \Phi
$$

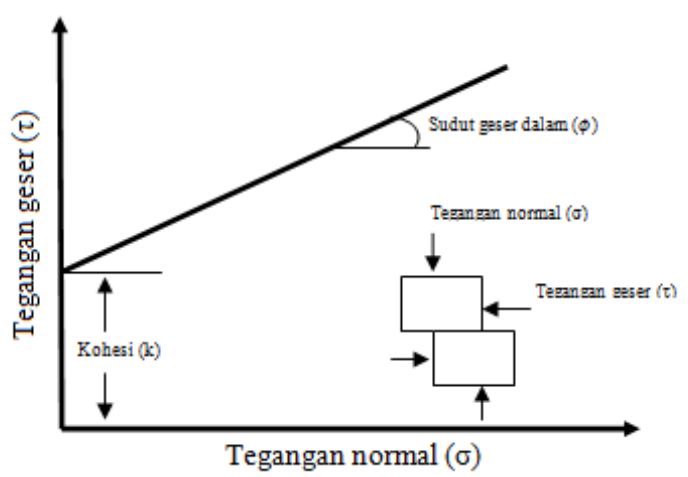

Gambar 8 Grafik hubungan kuat geser $(\tau)$ dengan tegangan normal $(\sigma)$

Metode perhitungan kesetimbangan batas yang paling sering digunakan untuk analisa longsoran tipe busur yaitu metode irisan Fellenius dan Bishop. Metode Fellenius mengasumsikan bahwa gaya-gaya yang bekerja antar irisan adalah nol. Penyelesaian tersebut meliputi penyelesaian ulang untuk gaya yang bekerja pada setiap irisan yang tegak lurus terhadap dasar. 
Metode Bishop yang disederhanakan merupakan salah satu metode perhitungan yang menggunakan kesetimbangan gaya dalam arah vertikal dan kesetimbangan momen pada pusat lingkaran bidang gelincir. Dalam metode ini, gaya geser antar irisan diasumsikan bernilai nol. Faktor Keamanan untuk metode perhitungan Bishop yang disederhanakan, dirumuskan sebagai berikut:

$$
F=\frac{\frac{\Sigma\left(\left(c^{\prime}+\left(\gamma \cdot h-\gamma_{w} \cdot h_{w}\right) \cdot \tan \phi\right) \cdot \frac{\Delta X}{\cos \alpha}\right)}{\left(1+\frac{Y \tan \alpha \cdot \tan \phi \prime}{F}\right)}}{\Sigma(\gamma \cdot h \cdot \Delta X \cdot \sin \alpha)+\left(\frac{1}{2} \gamma_{w} \cdot Z^{2} \cdot a / R\right)}
$$

$\mathrm{F}$ = faktor keamanan

$\gamma=$ bobot isi material (ton/m3)

$\gamma_{\mathrm{w}}=$ bobot isi air $(\operatorname{ton} / \mathrm{m} 3)$

$\alpha=$ kemiringan bidang gelincir $\left(^{\circ}\right)$

$\mathrm{h}$ = tinggi lereng $(\mathrm{m})$ $\mathrm{h}_{\mathrm{w}}=$ tinggi lereng jenuh $(\mathrm{m})$

$\mathrm{c}^{\prime}=$ kohesi $(\mathrm{MPa})$

$\mathrm{Z}=$ kedalaman tegangan tarik $(\mathrm{m})$

$\Phi^{\prime}=$ sudut geser dalam $\left(^{\circ}\right)$

Metode irisan merupakan metode yang umum digunakan dalam menganalisa kestabilan lereng maupun timbunan. Metode ini menyediakan sarana yang efektif untuk analisa kuantitatif. Gaya normal yang bekerja pada suatu titik di lingkaran longsor, terutama sangat dipengaruhi beban massa tanah/batuan di atasnya. Pada metode irisan, massa batuan yang longsor dibagi menjadi beberapa irisan vertikal. Penyelesaian nilai faktor keamanan membutuhkan sedikitnya satu asumsi yang berkaitan dengan gaya-gaya antar irisan (interslice forces). Asumsi yang umum digunakan berkaitan dengan arah, besar, dan titik kerja (point of application) dari gaya-gaya antar irisan. Setiap gaya yang bekerja pada masing-masing irisan tersebut dapat dilihat pada Gambar 9 di bawah ini.

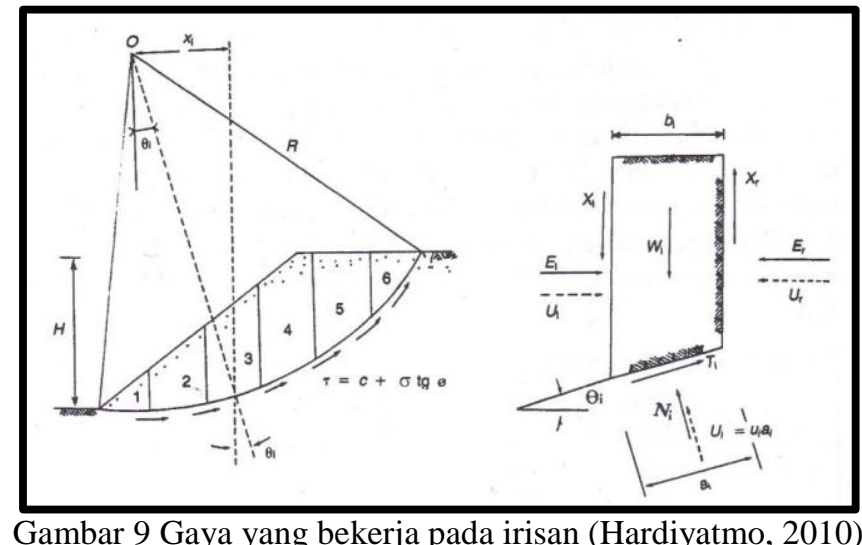

$\mathrm{Xi}, \mathrm{Xr} \quad$ = gaya geser efektif sepanjang sisi irisan

$\mathrm{Ei}, \mathrm{Er} \quad$ = gaya normal efektif sepanjang sisi irisan

$\mathrm{Ti}=$ resultan gaya geser efektid yang bekerja sepanjang dasar irisan

$\mathrm{Ni} \quad=$ resultan gaya normal efektif yang bekerja sepanjang dasar irisan

$\mathrm{Ui}, \mathrm{Ur} \quad=$ tekanan air pori yang bekerja pada kedua sisi irisan

Di dalam satu irisan terdapat tiga pesamaan kesetimbangan, yaitu kesetimbangan arah horizontal, vertikal, dan momen serta satu persamaan Mohr-Coulomb. Dengan demikian, untuk $n$ irisan akan terdapat $4 \mathrm{n}$ persamaan. Jumlah bilangan yang unknown sebanyak $6 \mathrm{n}-2$, sehingga persoalan tersebut merupakan persoalan statis tak tentu tingkat $(2 \mathrm{n}-2)$. Oleh karena itu, penyelesaian persoalan tersebut memerlukan asumsi agar menjadi statis tertentu. Setiap metode perhitungan memiliki asumsi yang berbeda sehingga penyelesaian yang diperoleh pun akan berbeda antar metode. 


\section{HASII DAN DISKUSI}

\section{Observasi Lapangan}

Distribusi massa batuan penyusun lereng yang ada di lokasi penelitian, beradasarkan dari beberapa log lubang bor, disajikan pada Gambar 10 di bawah. Mudstone, sanstone, dan batubara merupakan jenis massa batuan yang mendominasi dengan jumlah sekitar $80 \%$ dari total massa batuan penyusun lereng tambang di daerah penelitian. Material penyusun lereng lainnya merupakan soil dan jenis konglomerat.

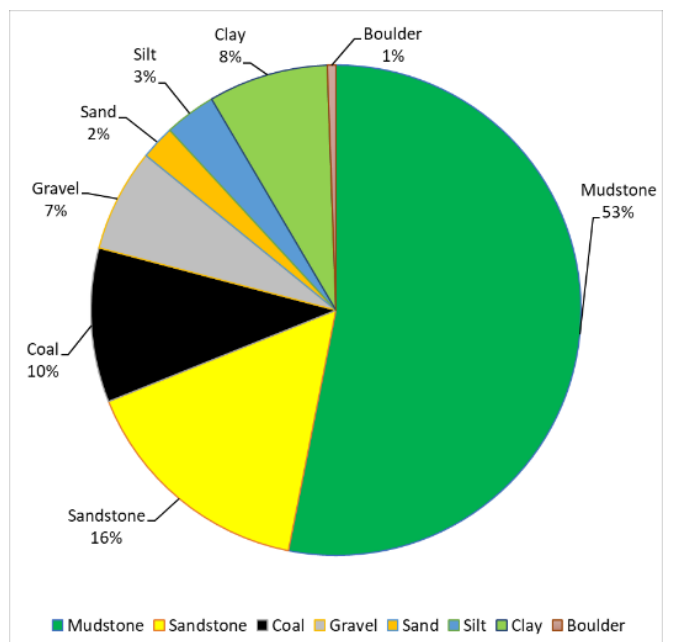

Gambar 10 Distribusi massa batuan penyusun lereng

Dari data log lubang bor menunjukkan bahwa distribusi kekuatan batuan padu (intact rock), setelah dikorelasikan dengan hasil tes laboratorium, tidak mengalami peningkatan selaras dengan penambahan kedalaman. Kekuatan intact rock berkisar dari Extremely Low (EL) hingga High (H) dengan proporsi yang signifikan pada Extremely Low (EL) dan Low (L). Intact rock dengan kekuatan yang extremely low ditemukan di antara beberapa interval kedalaman hingga RL+10.

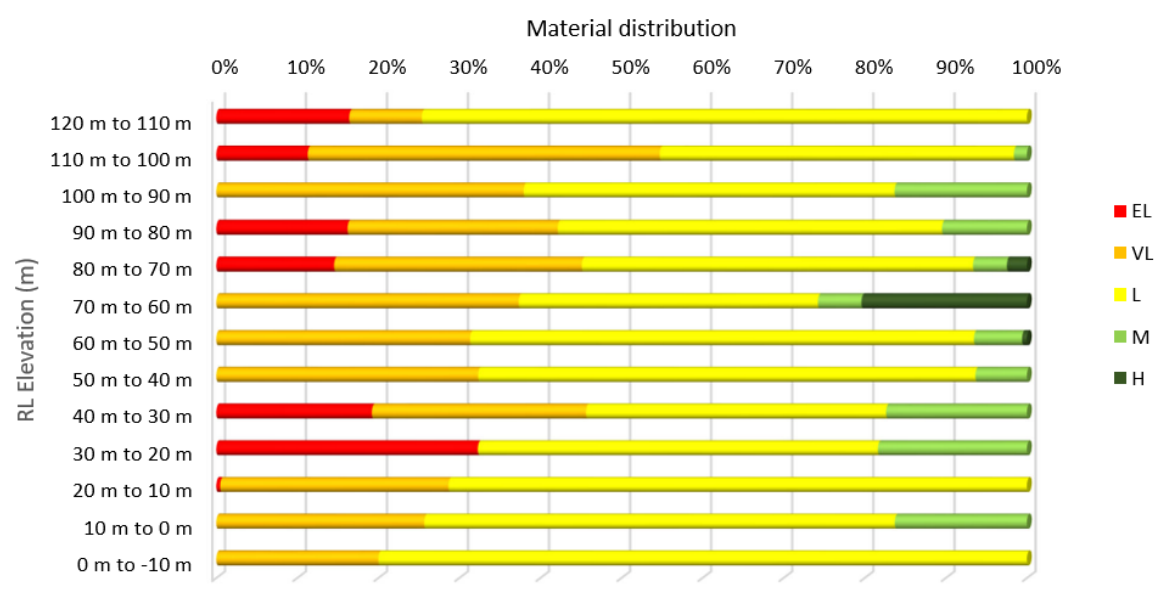

Gambar 11 Distribusi kekuatan intact rock (sumber: Golder Associates, 2018)

\section{Parameter Analisa}

Parameter kekuatan material penyusun lereng yang digunakan dalam analisa ini diperoleh dari hasil pengujian terdahulu terhadap sifat fisik dan sifat mekanik batuan conto daerah penelitian. Analisa dilakukan menggunakan metode kesetimbangan batas. Perhitungan kestabilan lereng dilakukan dengan mengikuti kriteria keruntuhan Mohr-Coulomb. Mekanisme longsoran lereng yang digunakan yaitu longsoran busur (circular). Muka air tanah dimodelkan berdasarkan data 
pengukuran pada lubang sumur pantau (piezometer hole) dan lokasi-lokasi seepage di area lereng tambang. Nilai seismic load yang digunakan sebesar 0,02g.

Tabel 1 Tabulasi data sifat mekanis material penyusun lereng daerah penelitian

\begin{tabular}{|c|c|c|c|}
\hline Litologi & $\gamma_{\text {sat }}\left(\mathbf{K N} / \mathbf{c m}^{\mathbf{3}}\right)$ & Kohesi $(\mathbf{K P a})$ & Sudut gesek dalam $\left(^{\circ}\right)$ \\
\hline Soil & 16,9 & 35 & 13,6 \\
\hline Ignimbrite & 18,52 & 75 & 21,25 \\
\hline Conglomerate & 20 & 63 & 27 \\
\hline Sandstone & 23 & 83 & 37 \\
\hline Claystone & 24 & 120 & 44 \\
\hline Claystone_2 & 24 & 80 & 26 \\
\hline Carbonaceous Mudstone & 22 & 64 & 20 \\
\hline Coal & 19 & 73 & 34 \\
\hline
\end{tabular}

\section{Hasil Analisa}

Analisa kestabilan lereng dilakukan dengan 1 penampang melintang (A-A') pada lereng sidewall dan 3 penampang melintang (B-B', C-C', dan D-D') pada lereng highwall tambang. Model geoteknik lereng disusun dengan memasukkan beberapa parameter yaitu geometri lereng, batas antar material, sifat fisik batuan, sifak mekanik batuan, faktor seismik, dan muka air tanah. Lokasi keempat penampang melintang tersebut dapat dilihat pada Gambar 12 di bawah ini. Analisa dilakukan untuk menghitung pengaruh penurunan muka air tanah terhadap nilai Faktor Keamanan kondisi lereng tambang pada desain rencana tahunan. Analisa dilakukan dengan variasi elevasi muka air tanah yang diturunkan per 10 meter, hingga didapatkan nilai Faktor Keamanan =1,30.

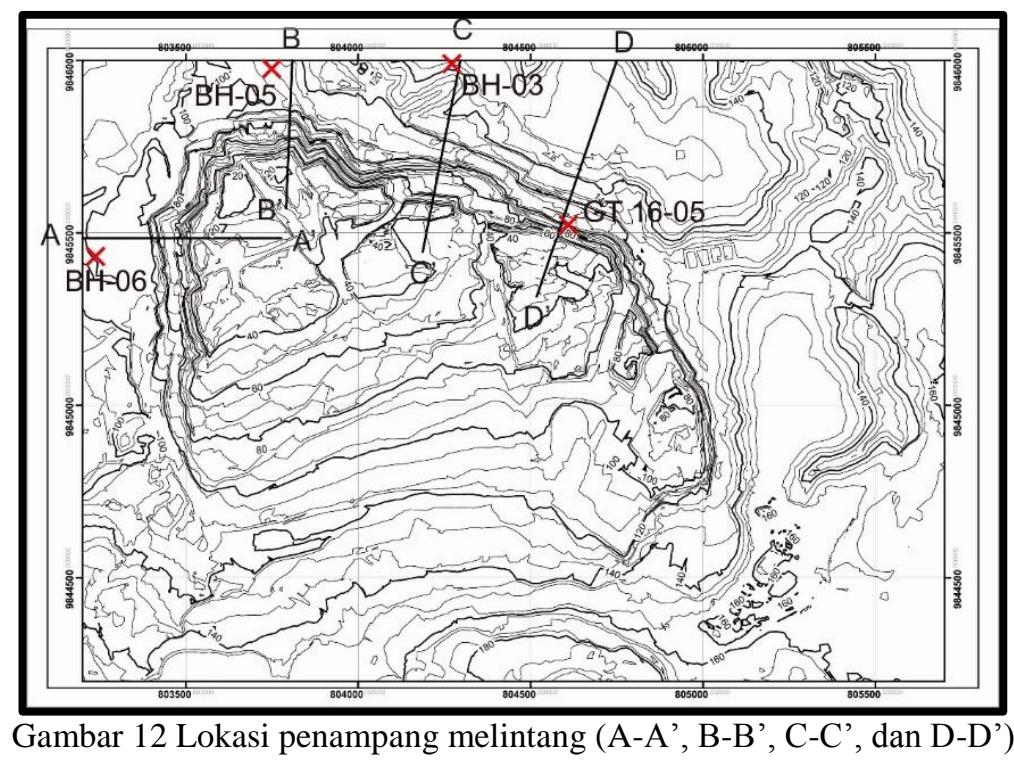

Berdasarkan hasil analisa dengan muka air tanah yang bervariasi, diketahui bahwa muka air tanah pada sebuah lereng memiliki pengaruh terhadap nilai Faktor Keamanan lereng tersebut. Hasil analisa menunjukkan hubungan berbanding terbalik antara muka air tanah dengan nilai Faktor Kamanan lereng. Penurunan muka air tanah pada lereng akan menyebabkan peningkatan nilai Faktor Keamanan lereng tersebut. Hasil analisa menunjukkan bahwa untuk mendapatkan nilai Faktor Keamanan $\geq 1,30$ pada lereng tambang daerah penelitian, muka air tanah pada lereng sidewall perlu diturunkan hingga elevasi RL+40 dan pada lereng highwall perlu diturunkan hingga elevasi RL+65. 

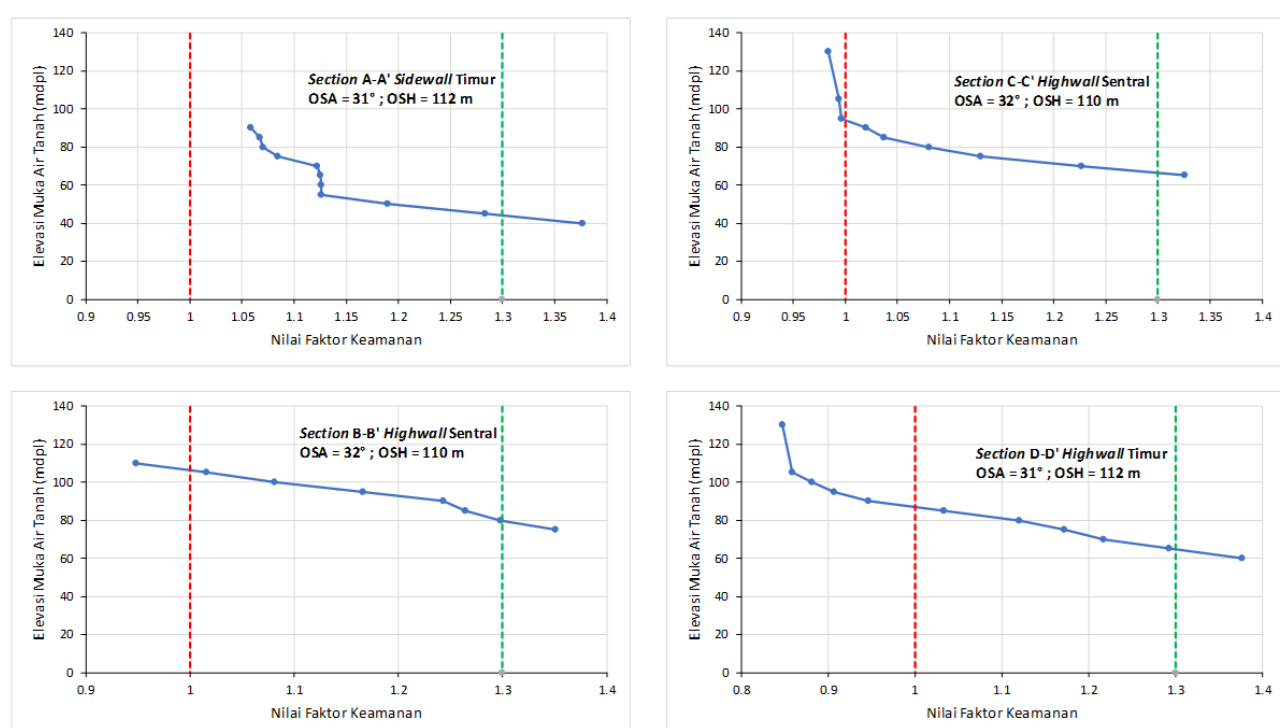

Gambar 13 Grafik pengaruh elevasi muka air tanah terhadap nilai Faktor Keamanan

Selain analisa dengan pemodelan muka air tanah yang bervariasi, dilakukan juga analisa dengan rencana pelandaian sudut kemiringan lereng keseluruhan. Analisa ini dilakukan dengan asumsi muka air tanah alami, sesuai dengan data pemantauan sumur pantau (piezometer hole).
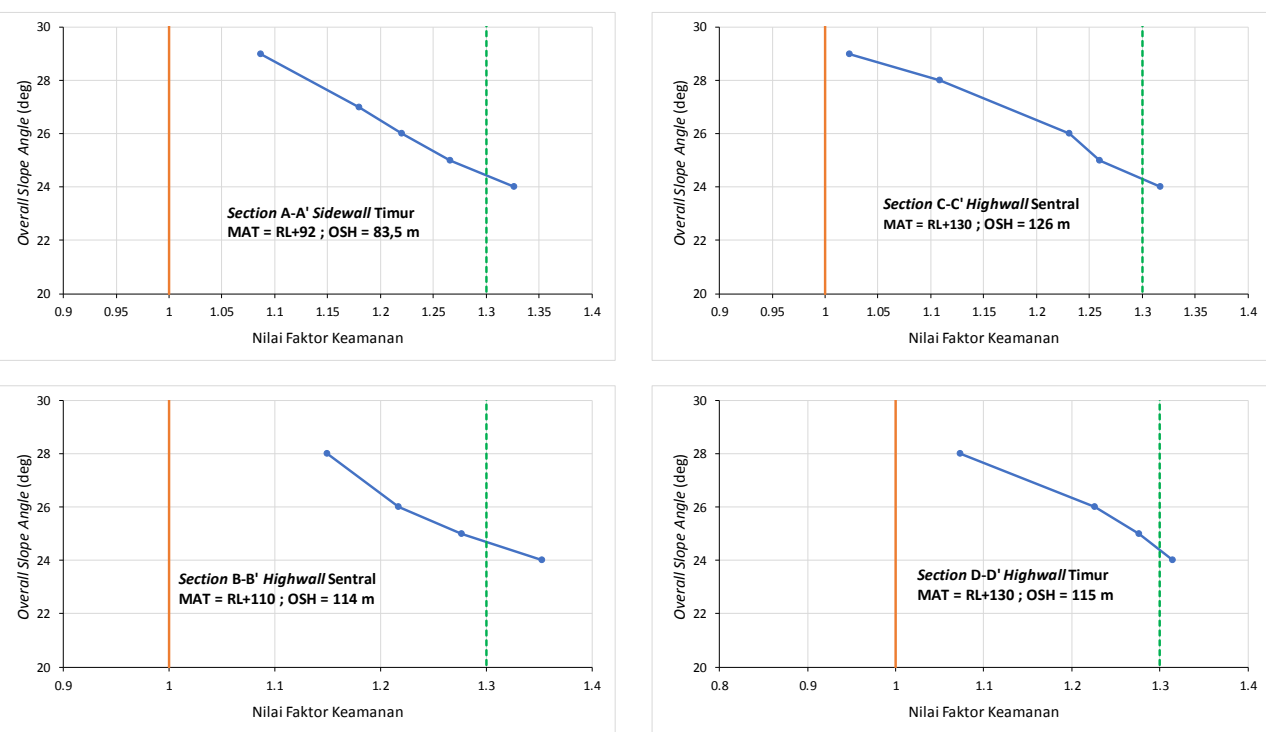

Gambar 14 Grafik pengaruh overall slope angle terhadap nilai Faktor Keamanan

Berdasarkan hasil analisa pada rencana pelandaian sudut kemiringan lereng keseluruhan, diketahui bahwa sudut kemiringan lereng keseluruhan berdampak pada nilai Faktor Keamanan lereng tersebut. Seperti halnya dengan pengaruh muka air tanah, hasil analisa menunjukkan hubungan berbanding terbalik antara sudut kemiringan lereng keseluruhan dengan nilai Faktor Kamanan lereng. Semakin landai lereng yang dibentuk, akan menghasilkan nilai Faktor Keamanan yang semakin meningkat. Hasil analisa kestabilan lereng di atas menunjukkan bahwa lereng tambang baik sidewall maupun highwall perlu dilakukan pelandaian (layback) dengan sudut kemiringan keseluruhan $\leq 24^{\circ}$.

Dari hasil analisa yang dilakukan terhadap dua model kondisi lereng desain rencana tahunan, menunjukkan nilai Faktor Keamanan (FK) lereng < 1,30. Hal ini mengindikasikan lereng termasuk kelas labil - kritis (Bowles, 1989). Oleh karena itu, sangat direkomendasikan untuk dilakukan 
upaya slope engineering untuk menaikkan nilai Faktor Keamanan lereng. Secara umum upaya stabilisasi lereng dapat dilakukan dengan menambah gaya penahan atau mengurangi gaya penggerak yang bekerja pada lereng. Dalam studi ini, upaya stabilisasi yang diusulkan adalah dengan mengurangi gaya penggerak. Metode yang diusulkan yaitu dengan melakukan depressurization melalui drain hole maupun dengan melakukan pelandaian (layback) lereng keseluruhan.

\section{KESIMPULAN}

Berdasarkan hasil analisa kestabilan lereng yang telah dilakukan, penulis menarik beberapa kesimpulan, yaitu:

1) Keberadaan dan muka air tanah pada sebuah lereng tambang memiliki pengaruh terhadap kestabilan lereng tersebut.

2) Penurunan muka air tanah memiliki hubungan berbanding terbalik dengan peningkatan nilai Faktor Keamanan sebuah lereng.

3) Untuk mencapai nilai Faktor Keamanan standar $(\mathrm{FK}=1,30)$, diusulkan dilakukan upaya depressurization dengan target muka air tanah pada elevasi RL+40 untuk sidewall sisi Barat dan RL+60 untuk area highwall.

4) Upaya lain terkait peningkatan kestabilan lereng yang diusulkan adalah dengan melakukan pelandaian (layback) lereng, dengan target sudut lereng keseluruhan (overall slope angle) $25^{\circ}$.

5) Sistem manajemen seepage dan drainase air permukaan di daerah penelitian perlu diperhatikan.

6) Kajian lanjutan terkait hidrogeologi dan tekanan air pori pada lereng highwall perlu dilakukan.

\section{UCAPAN TERIMA KASIH}

Penulis mengucapkan terima kasih kepada karyawan dan manajemen Golden Energy Mines (GEMS) dan semua pihak terkait atas dukungannya sehingga makalah ilmiah ini dapat selesai.

\section{DAFTAR PUSTAKA}

Alloisio, S., Douglas, B., McKittrick, R., \& Prigneau, P. (2004): Groundwater modelling for largescale mine dewatering in Chile: MODFLOW or FEFLOW? . Shrewsburry.

Arif, I. (2010): Geoteknik Tambang. Program Studi Teknik Pertambangan ITB. Bandung. 2010.

Bester, M., Nel, E., \& Gavigan, G. (2013): A Strategic Approach to the Design and Implementation of an Effective Mine Dewatering System. Slope Stability (hal. 1-16). Brisbane: Australian Centre for Geomechanics.

Bishop, A.W. (1955): The Use of the Slip Circle in the Stability Analysis of Slopes. Geotechnique vol. 5.

Bishop, A.W., dan Bjerrum, L. (1960): The Relevance of the Triaxial Test to the Solution of Stability Problems. ASCE Conference on Strength of Cohesive Soils.

Bishop, A.W., dan Morgenstern, N. (1960): Stability Coefficients for Earth Slopes. Geotechnique vol. 19.

Bowles, E.J. (1989): Sifat-sifat Fisis dan Geoteknis Tanah. Penerbit Erlangga. Jakarta.

Fellenius, W. (1936): Calculation of the Stability of Earth Dams. Trans. 2nd Cong. on Large Dams vol 4. Washington.

Golder Associates. (2018): Geotechnical Investigation for Pit and Waste Dump Studies Report.

Hardiyatmo, H.C. (2010): Mekanika Tanah 1. Gadjah Mada University Press. Yogyakarta.

Hardiyatmo, H.C. (2010): Mekanika Tanah 2. Gadjah Mada University Press. Yogyakarta. 
Johansson, J. (2014): Impact of Water-Level Variations on Slope Stability. Lulea University of Technology.

LAPI ITB, PT. (2017): Studi Pengaruh Getaran Peledakan Terhadap Perumahan Penduduk dan Evaluasi Kestabilan Lereng Tambang PT Kuansing Inti Makmur Site Muara Bungo, Jambi.

Muntohar, A.S., dan Saputro, R.I. (2014): Pengaruh Kedalaman Muka Air Tanah Awal Terhadap Analisis Stabilitas Lereng Tak Jenuh. Seminar Nasional X - 2014. Teknik Sipil ITS Surabaya.

Rahardjo, H., Hritzuk, K., Leong, E., \& Rezaur, R. (2003): Effectiveness of horizontal drains for slope stability. Engineering Geology, 295-308.

Rai, M.A., Kramadibrata, S., dan Wattimena, R.K. (2007): Mekanika Batuan. Penerbit ITB. Bandung.

Rosidi, H.M.D., Tjokrosapoetro, S., Pendowo, B., Gafoer, S., dan Suharso. (1996): Peta Geologi Lembar Painan dan Bagian TimurLaut Lembar Muarasiberut, Sumatera. Pusat Penelitian dan Pengembangan Geologi.

Sugianti, K. (2013): Pengaruh Muka Airtanah terhadap Kestabilan Lereng pada Ruas Jalan Raya Cadaspangeran, Sumedang. Riset Geologi Tambang Vol.22 No.2, 117-125. 
PROSIDING TPT XXVIII PERHAPI 2019 